\title{
Floorplan Congress Centre and Exhibition
}

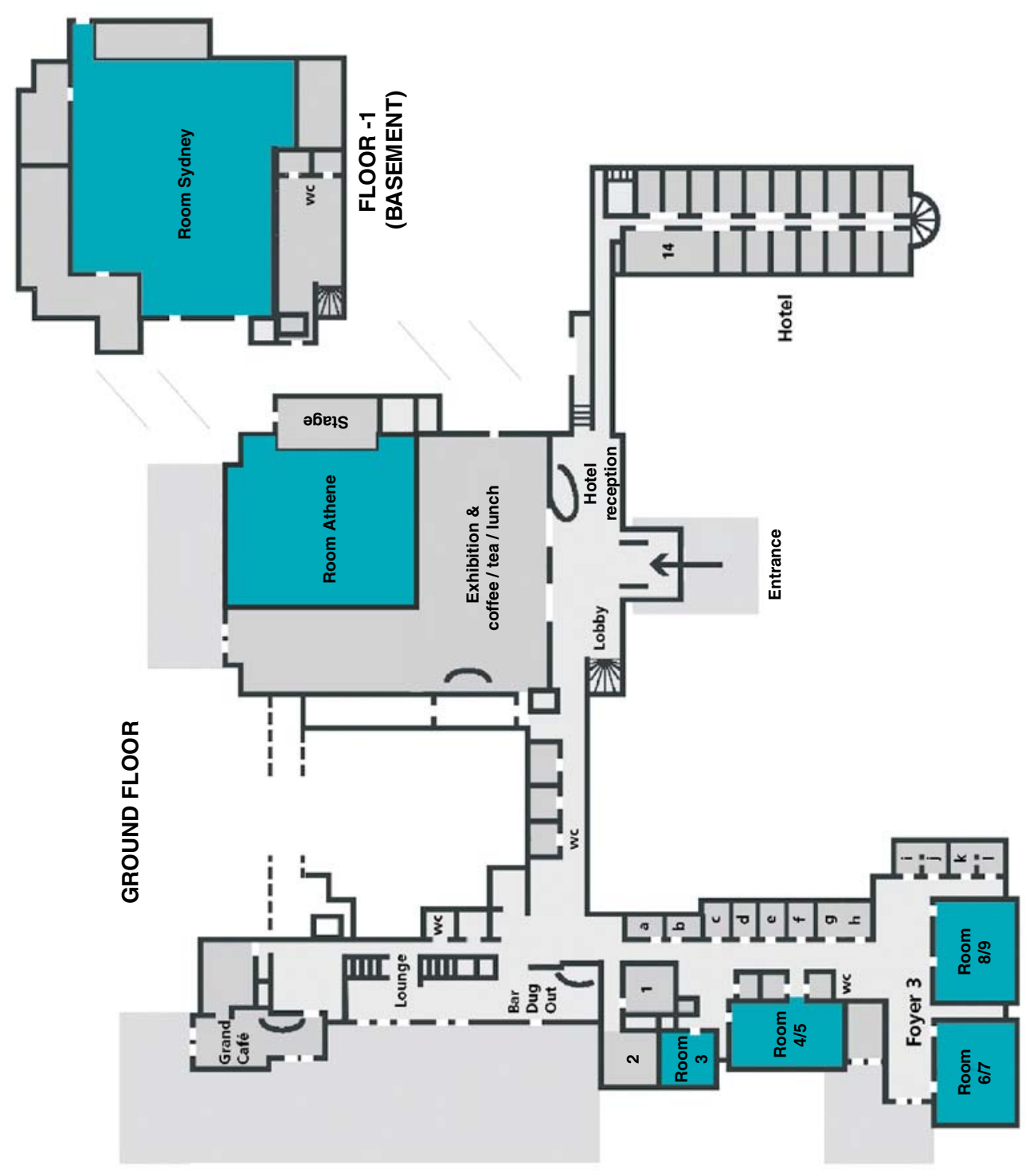

Fig. 1 Floorplan Congress Centre 


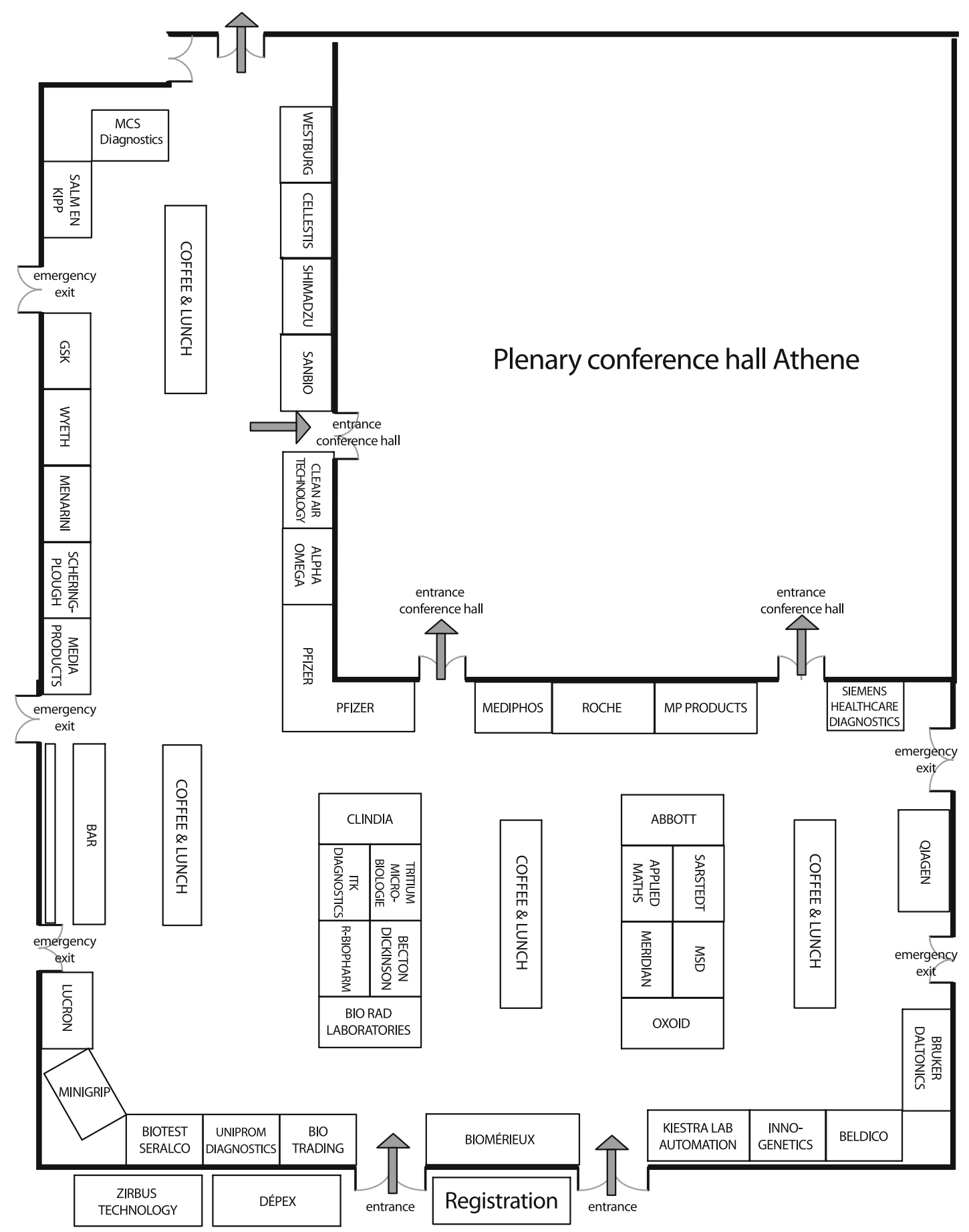

Fig. 2 Floorplan Exhibition 